\title{
Gene Transfer into Cardiac Myocytes
}

\author{
Sarah E. Lang and Margaret V. Westfall
}

\begin{abstract}
Traditional methods for DNA transfection are often inefficient and toxic for terminally differentiated cells, such as cardiac myocytes. Vector-based gene transfer is an efficient approach for introducing exogenous cDNA into these types of primary cell cultures. In this chapter, separate protocols for adult rat cardiac myocyte isolation and gene transfer with recombinant adenovirus are provided and are routinely utilized for studying the effects of sarcomeric proteins on myofilament function.
\end{abstract}

\section{Keywords}

Adenovirus; Gene transfer; Cardiomyocytes; Homologous recombination; Cardiac; Myocyte isolation

\section{Introduction}

The ability to introduce cDNA into primary cell culture is often essential for identifying the structural and/or functional role of a protein [1]. Genetic animal models are ultimately desirable for gaining insight into the role one or more proteins play in modulating or regulating cardiac pump performance. However, studies in primary adult myocytes can effectively bridge the gap between biochemical/molecular experiments and studies in more complex in vivo models [1-3]. In many organ systems, immortalized cells are available to help bridge these gaps. Cardiac cell lines, such as HL-1 cells, are available and are usually amenable to typical transfection approaches for gene transfer, such as lipofectamine [4-6]. However, currently available cardiac cell lines are unable to completely recapitulate the terminally differentiated, rod-shaped morphology and contractile function produced by adult myocytes. As a result, isolated adult myocytes continue to be the most utilized model for cellular studies, particularly for work related to cardiac contractile performance $[7,8]$.

Single cell work in adult cardiac myocytes has provided significant insights into $\mathrm{Ca}^{2+}$ cycling and the role played by individual sarcomeric proteins in modulating contractile function $[2,7,9]$. Protein expression and the subsequent functional response can be measured over several hours to days in cells, making isolated myocytes a cost-effective approach for studying cardiac function [1, 7, 9]. In contrast to cell lines, transfection of terminally differentiated adult cardiac myocyte is often toxic [9-11]. Additional approaches, such as poly-L-ornithine, have proven to be less toxic but are inefficient and fail to produce 
adequate protein expression [9]. Recombinant virus is an alternative approach for efficient and nontoxic gene transfer into many cells, including adult myocytes.

Multiple types of virus are available for gene transfer, including both integrative and nonintegrative vectors $[9,10,12-16]$. Single-stranded, RNA virus, such as the popular lentiviral vector, integrate into the host genome and result in germ-line transmission [12, 13, 17, 18]. Lentiviral constructs are capable of gene transfer into many cell types and can produce persistent global or tissue-specific transgene expression [19-22], making lentivirus a desirable tool for long-term and/or in vivo studies. Lentiviral integration is stochastic and can result in insertional mutagenesis if positioned adjacent to an oncogene, which requires consideration when using this vector for in vivo gene delivery [12, 13, 18]. Efficient and sustained long-term expression also is achieved with other integrating vectors, such as adeno-associated virus (AAV). Rather than RNA, AAV contains single stranded DNA and it is increasingly utilized for gene therapy [23]. A portion of the AAV genome integrates sitespecifically on chromosome 19 and as episomal genomes. Recombinant AAV vectors also can be constructed to produce gene targeting via homologous recombination [24, 25]. However, protein production for both lentiviral and AAV vector-mediated gene transfer is preceded by a latent or lag phase due to viral integration [23, 26]. This latency can be a disadvantage for shorter-term cell culture studies in isolated cells. Isolated adult myocyte studies are typically performed within a week of isolation, as these cells are cultured in serum-free media to maintain the adult, rod-shaped morphology. Clearly, the specific characteristics of each vector are important to consider for optimal in vivo and in vitro experiments.

The linear, non-integrative and double-stranded recombinant adenovirus is an alternative vector used for gene transfer. This vector is ideal for cellular studies because it produces rapid and efficient gene expression in a large number of cell types due to the ubiquitous expression of the receptor required for viral entry [27-29]. In primary cultures of cardiac myocytes, adenoviral-mediated gene transfer produces rapid and efficient gene transfer and expression. Thus, gene transfer using recombinant adenoviral constructs has produced substantial insights into cardiac cellular function, including myofilament function. Most importantly, insights into contractile performance can usually be achieved in intact myocytes without vector-dependent disruption of sarcomere stoichiometry, myofilament integrity, or contractile function [2, 9, 30-36]. A limiting factor for in vivo gene transfer is the immune response to adenovirus in animal models, which generally prevents transgene expression beyond 2 weeks post-gene transfer [11,37].

Our laboratory routinely utilizes recombinant adenoviral-mediated gene transfer into isolated adult rat cardiac myocytes. The two plasmid Cre-loxP system available from Microbix (Toronto, CA) can generate the high titer recombinant adenoviral constructs used for studies in myocytes, and is described elsewhere [2, 11, 38, 39]. This chapter outlines our current protocol for the isolation of $\mathrm{Ca}^{2+}$-tolerant, rod-shaped adult rat myocytes and the use of high titer recombinant adenovirus for gene transfer into these cells. A brief section also provides information about culturing these cells in serum-free media for 5-7 days [2, 9]. The protocol is adapted from the method developed by Haworth et al. to produce $1-2 \times 10^{6}$ 
cardiac myocytes [40]. These protocols are optimized for adult rat hearts and require adaptation for myocytes isolated from other species $[35,41]$.

\section{Materials}

All solutions should be prepared with purified, deionized water $\left(\mathrm{dH}_{2} \mathrm{O} ; 18 \Omega\right)$.

\subsection{Reagents and Supplies for Isolation of Adult Rat Cardiac Myocyte}

1. Perfusion setup: A Baker apparatus (Harvard “Baker" perfusion set \#50-8382) is used for this protocol and has a double-barrel warming coil with an upper, changeover stopcock to regulate flow from syringes containing perfusion buffers

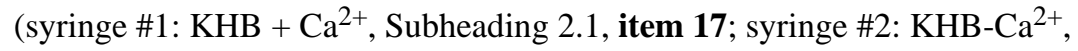
Subheading 2.1, item 16) (see Note 1). Two $50 \mathrm{~mL}$ glass syringes are attached to the warming coil by tubing and are positioned to achieve a $70 \mathrm{mmHg}$ gravimetric pressure difference between the syringe and the heart. Unless otherwise noted, all tubing used for the Baker apparatus is Tygon ${ }^{\circledR}$ tubing. Two pieces of tubing also are connected to the top of the warming coil with the opened ends positioned at the same height as the syringes to serve as bubble traps. Two additional pieces of tubing are attached to the sides of the warming coil to adjust and drain buffers. Stopcocks are attached to the end of each set of drain tubing and these stopcocks are closed in between cell isolations. A final piece of tubing is inserted into the bottom of the warming chamber and connected to a second, smaller stopcock (i.e., the lower stopcock) to hold the heart mounted to a tubing adapter. The Baker warming chamber temperature is kept at $37^{\circ} \mathrm{C}$ by constant water flow from a circulating water bath through a water inlet and outlet within the warming chamber. A small piece of PE-20 tubing connected to Tygon ${ }^{\circledR}$ tubing is used to collect effluent from the heart, returning it to syringe \#2 using a peristaltic pump as a means of continuously reperfusing the heart during the digestion phase of the perfusion [2].

2. The surgical tools for this procedure include: one pair Mayo-Stille scissors, one standard pattern forceps, one pair of fine dissection scissors, two pairs of Dumont \#4 forceps, a Bellco Cellector tissue sieve (mesh size: $230 \mu \mathrm{m}$ ), and a 16-G tubing adapter (i.e., cannula). Surgical tools should be autoclaved prior to the myocyte isolation and handled to maintain sterility during the cell isolation procedure.

3. Sterile glassware used for myocyte isolations include: $3-50 \mathrm{~mL}$ glass beakers, $1-25$ $\mathrm{mL}$ glass beaker, $1-100 \mathrm{~mL}$ glass beaker.

4. Silanized trituration pipets (two pipets—one large bore, one smaller bore). These pipets are prepared by marking a Pasteur pipet with a diamond knife, cleanly breaking off the stem, and fire polishing the glass prior to their first use. Trituration pipets are washed in $7 \times$ soap, rinsed thoroughly with $\mathrm{dH}_{2} \mathrm{O}$, silanized in

\footnotetext{
${ }^{1} \mathrm{Be}$ sure to use the same KHB buffer $\left(+\right.$ or $-\mathrm{Ca}^{2+}$ ) for the duration of the experiment. One suggestion is to mark the syringe and the corresponding KHB bottle with the same color tape to avoid confusing the buffers.
} 
Sigmacote ${ }^{\circledR}$, and then allowed to dry. Each pipet is auto-claved after drying the silanized coating.

5. Sterile $\mathrm{dH}_{2} \mathrm{O}$ : Filter-sterilize $1 \mathrm{~L} \mathrm{dH}_{2} \mathrm{O}$. Unless otherwise noted, filter-sterilized solutions described below are sterilized using a $0.22 \mu \mathrm{m}$ bottle-top filter and stored at room temperature for up to 1 month (see Note 2).

6. Heparin: Heparin sodium injection (1,000 USP units/mL).

7. Nembutal: Pentobarbital sodium $(50 \mathrm{mg} / \mathrm{mL})$.

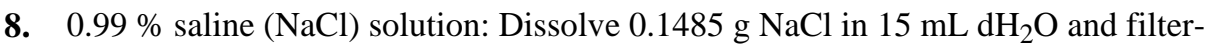
sterilize.

9. $70 \%$ ethyl alcohol: Dilute $700 \mathrm{~mL}$ ethyl alcohol (200 proof) with $\mathrm{dH}_{2} \mathrm{O}$ to a final volume of $1 \mathrm{~L}$.

10. $50 \mathrm{U} / \mathrm{mL}$ Penicillin-50 $\mu \mathrm{g} / \mathrm{mL}$ Streptomycin $(\mathrm{P} / \mathrm{S})+$ sterile $\mathrm{dH}_{2} \mathrm{O}$ : Add $10 \mathrm{~mL} \mathrm{P/S}$ into $\mathrm{dH}_{2} \mathrm{O}$, bring to a final volume of $1 \mathrm{~L}$, and filter-sterilize.

11. $1 \mathrm{M} \mathrm{NaCl}$ : Dissolve $58.44 \mathrm{~g} \mathrm{NaCl}$ in a final volume of $1 \mathrm{~L} \mathrm{dH}_{2} \mathrm{O}$ and filtersterilize.

12. $0.5 \mathrm{M} \mathrm{KCl}$ : Dissolve $37.27 \mathrm{~g} \mathrm{KCl}$ in a final volume of $1 \mathrm{~L} \mathrm{dH}_{2} \mathrm{O}$ and filter-sterilize.

13. $0.5 \mathrm{M} \mathrm{KH}_{2} \mathrm{PO}_{4}$ : Dissolve $68.05 \mathrm{~g} \mathrm{KH}_{2} \mathrm{PO}_{4}$ to a final volume of $1 \mathrm{~L}$ with $\mathrm{dH}_{2} \mathrm{O}$ and filter-sterilize.

14. $100 \mathrm{mM} \mathrm{MgSO} 4 \times 7 \mathrm{H}_{2} \mathrm{O}$ : Dissolve $24.65 \mathrm{~g} \mathrm{MgSO}_{4} \times 7 \mathrm{H}_{2} \mathrm{O}$ to a final volume of 1 $\mathrm{L}$ with $\mathrm{dH}_{2} \mathrm{O}$ and filter-sterilize.

15. $100 \mathrm{mM} \mathrm{CaCl}_{2} \times 2 \mathrm{H}_{2} \mathrm{O}$ : Dissolve $14.70 \mathrm{~g} \mathrm{CaCl}_{2} \times 2 \mathrm{H}_{2} \mathrm{O}$ in a final volume of $1 \mathrm{~L}$ with $\mathrm{dH}_{2} \mathrm{O}$, and filter-sterilize.

16. $\mathrm{Ca}^{2+}$-Free Krebs-Henseleit Buffer $\left(\mathrm{KHB}_{-} \mathrm{Ca}^{2+}\right)$ : Mix $118.0 \mathrm{~mL} 1 \mathrm{M} \mathrm{NaCl}, 9.60$ $\mathrm{mL} 0.5 \mathrm{M} \mathrm{KCl}, 2.40 \mathrm{~mL} 0.5 \mathrm{M} \mathrm{KH}_{2} \mathrm{PO}_{4}$, and $12.0 \mathrm{~mL} 100 \mathrm{mM} \mathrm{MgSO}_{4} \times 7 \mathrm{dH}_{2} \mathrm{O}$ in $\sim 600 \mathrm{~mL} \mathrm{dH}_{2} 0$. Add $6.50 \mathrm{~g}$ HEPES buffer and $1.98 \mathrm{~g}$ Glucose. Adjust the $\mathrm{pH}$ to 7.4 with $1 \mathrm{M} \mathrm{HCl}$ and a final volume of $1 \mathrm{~L}$ with $\mathrm{dH}_{2} \mathrm{O}$. The solution is filtersterilized and stored at $4{ }^{\circ} \mathrm{C}$ for a maximum of 2 weeks (see Note 3).

17. $\mathrm{KHB}$ with $\mathrm{Ca}^{2+}\left(\mathrm{KHB}+\mathrm{Ca}^{2+}\right)$ : Prepare $\mathrm{KHB}$ as described in Subheading 2.1, item 16 and add $10 \mathrm{~mL} 100 \mathrm{mM} \mathrm{CaCl}_{2} \times 2 \mathrm{H}_{2} \mathrm{O}$ to the solution prior to the addition of $6.50 \mathrm{~g}$ HEPES buffer and $1.98 \mathrm{~g}$ Glucose. Adjust the $\mathrm{pH}$ to 7.4, bring the final volume of the solution to $1 \mathrm{~L}$, filter-sterilize, and store the solution at $4{ }^{\circ} \mathrm{C}$ for a maximum of 2 weeks.

18. Hyaluronidase (Type IV-S; bovine testes, embryo tested): Thaw hyaluronidase on ice and resuspend to $10 \mathrm{mg} / \mathrm{mL}$ with autoclaved $\mathrm{dH}_{2} \mathrm{O}$. Aliquot hyaluronidase into

\footnotetext{
${ }^{2}$ Stock solutions can be stored at room temperature for up to 1 month. If the solutions become cloudy, make fresh solutions prior to the myocyte isolation.

${ }^{3}$ Older $\mathrm{KHB}+\mathrm{Ca}^{2+}$ (Subheading 2.1 item 17) and $\mathrm{KHB}-\mathrm{Ca}^{2+}$ (Subheading 2.1 item 16) can be used to rinse the apparatus after the wash steps (Subheading 3.1.1 \#3-4). Fresh KHB should be used for each myocyte isolation.
} 
prechilled $0.5 \mathrm{~mL}$ microfuge tubes and store at $-20{ }^{\circ} \mathrm{C}$. Avoid freeze-thawing the hyaluronidase aliquots.

19. Collagenase, Type 2: Store lyophilized collagenase in a sealed and desiccated container at $4{ }^{\circ} \mathrm{C}$. Calculate the amount of collagenase needed for cardiac myocyte isolation based on the specific lot of collagenase, type 2 (see Note 4).

20. Digestion solution: Add hyaluronidase ( $300 \mu \mathrm{g} / \mathrm{mL}$; Subheading 2.1, item 18) and fresh collagenase (75-90 U/mL; Sub-heading 2.1 , item 19) to $25 \mathrm{~mL}$ of KHB-Ca ${ }^{2+}$ (Subheading 2.1, item 16) in a sterile $50 \mathrm{~mL}$ beaker. The digestion solution should be made with fresh collagenase for each cell isolation procedure. Store solution in a $37{ }^{\circ} \mathrm{C}$ humidified, $5 \% \mathrm{CO}_{2}$ incubator for a maximum of $3 \mathrm{~h}$ prior to use.

\subsection{Reagents for Gene Transfer and Cell Culture}

1. Laminin (mouse): Store laminin at $-80^{\circ} \mathrm{C}$ and thaw on ice just prior to dilution in sterile phosphate buffered saline ( $1 \times$ PBS). Laminin is diluted to a concentration of $40 \mu \mathrm{g} / \mathrm{mL}$, aliquoted into one-use prechilled microfuge tubes, and stored at $-20{ }^{\circ} \mathrm{C}$ for up to 6 months.

2. Cell equilibration media ( $\mathrm{KHB}+\mathrm{Ca}^{2+}$ and $2 \%$ Bovine Serum Albumin [BSA]): Dissolve $2 \mathrm{~g}$ of BSA (Fraction V, heat-shocked, fatty acid free) in $100 \mathrm{~mL} \mathrm{KHB} \mathrm{+}$ $\mathrm{Ca}^{2+}$ (Subheading 2.1, item 17). Filter-sterilize media and store at $4{ }^{\circ} \mathrm{C}$ for up to 2 weeks.

3. DMEM + P/S: Add $5 \mathrm{~mL}$ P/S (Subheading 2.1, item 10) to $500 \mathrm{~mL}$ Dulbecco's modified Eagle's medium (DMEM; high glucose with L-glutamine), filter-sterilize, and store at $4{ }^{\circ} \mathrm{C}$ for up to 2 weeks.

4. $\mathrm{DMEM}+10 \% \mathrm{FBS}+\mathrm{P} / \mathrm{S}$ : Add $10 \mathrm{~mL}$ fetal bovine serum (FBS; premium) to 90 $\mathrm{mL}$ DMEM + P/S (Subheading 2.2, item 3). Filter-sterilize media and store at $4{ }^{\circ} \mathrm{C}$ for up to 2 weeks.

5. M199 + P/S: Mix M199 (1x; HEPES modification with Earle's salts and $\mathrm{L}_{-}$ glutamine) with $3.073 \mathrm{~g}_{\mathrm{L}}$-glutathione, $200 \mathrm{mg}$ BSA (Fraction V, heat shock, fatty acid free), $2.2 \mathrm{~g} \mathrm{NaH}_{2} \mathrm{CO}_{2}$, and $2.6 \mathrm{~g}$ HEPES buffer in $\mathrm{dH}_{2} \mathrm{O}$. Adjust the $\mathrm{pH}$ to 7.4 with $1 \mathrm{M} \mathrm{NaOH}$, add $10 \mathrm{~mL}$ of $\mathrm{P} / \mathrm{S}$ and then bring the volume to $1 \mathrm{~L}$ with $\mathrm{dH}_{2} \mathrm{O}$. Filter-sterilize the media into two, sterile $500 \mathrm{~mL}$ bottles, and store at $4{ }^{\circ} \mathrm{C}$ for up to 2 weeks.

\section{Methods}

\subsection{Isolation of Adult Cardiac Myocytes from Rat Hearts 3.1.1 Preparing for Myocyte Isolation}

1. $\mathrm{KHB}_{-\mathrm{Ca}^{2+}}$ (Subheading 2.1 , item 16) and $\mathrm{KHB}+\mathrm{Ca}^{2+}$ (Subheading 2.1, item 17) should be pre-warmed at $37^{\circ} \mathrm{C}$ prior to use.

\footnotetext{
${ }^{4}$ This protocol is optimized for collagenase Type 2 containing $5750 \mathrm{U}$ collagenase, $12,800 \mathrm{U}$ caseinase, $80.5 \mathrm{U}$ clostripain, and $4.6 \mathrm{U}$ trypsin per milligram of lyophilized powder.
} 
2. All "open" tubes should be covered tightly with Parafilm between cell isolations. Just prior to each cell isolation, remove Parafilm from all openings, place Pyrex gas dispersion tube (e.g., oxygenator) in syringe \#1 $\left(\mathrm{KHB}+\mathrm{Ca}^{2+}\right.$ syringe) and adjust delivery of gas $\left(95 \% \mathrm{O}_{2}, 5 \% \mathrm{CO}_{2}\right)$ to achieve a gentle release of $\mathrm{O}_{2}$.

3. Turn on the water bath to begin heating the Baker perfusion manifold to $37^{\circ} \mathrm{C}$. Wash the perfusion apparatus, syringes \#1 and \#2 and all tubing with $70 \%$ ethyl alcohol (Subheading 2.1, item 9), then sterile $\mathrm{dH}_{2} \mathrm{O}(x 2)$ (Subheading 2.1, item 5), and finally sterile $\mathrm{dH}_{2} \mathrm{O}$ with $\mathrm{P} / \mathrm{S}$ (Subheading 2.1, item 10). Ensure both the primary tubing and the bubble traps and drains are treated with ethyl alcohol and then thoroughly rinsed with $\mathrm{dH}_{2} \mathrm{O}$ to remove all traces of ethyl alcohol prior to the next step.

4. Turn the changeover stopcock to closed position while keeping the lower stopcock in an open position. Fill syringe \#1 and the attached tubing with pre-warmed KHB $+\mathrm{Ca}^{2+}$ (Subheading 2.1, item 17). Fill syringe \#2 with pre-warmed KHB-Ca ${ }^{2+}$ (Subheading 2.1 item 16) (see Note 1). Remove all air bubbles in the tubing while flushing the setup with KHB from each syringe (see Note 3). Once air bubbles are removed, perform a final flush with $\mathrm{KHB}+\mathrm{Ca}^{2+}$. Then, keep the upper stopcock in the syringe \#1 open position. Close the lower stopcock until the heart is ready to mount. Do not allow the syringes and tubing to empty once the flushing process is complete. Oxygenate the $\mathrm{KHB}+\mathrm{Ca}^{2+}$ buffer for $10-15$ min prior to heart perfusion.

5. Fill a large bucket with ice loaded to be even with the rim of the bucket. Place both the top and bottom portions of a cell culture dish on the ice. Fill each portion with $50 \mathrm{~mL} \mathrm{KHB}+\mathrm{Ca}^{2+}$ (Subheading 2.1 item 17) and keep one on ice. Fill a $10 \mathrm{~mL}$ syringe with ice-cold $\mathrm{KHB}+\mathrm{Ca}^{2+}$, attach the cannula, and remove air bubbles from the syringe. Place cannula (i.e. tubing adapter) at a $90^{\circ}$ angle above the ice bucket and position the syringe at a $\sim 45^{\circ}$ angle toward to ice bucket. Angle the syringe using the tube holder so that the cannula tip is just below the surface of the $\mathrm{KHB}+\mathrm{Ca}^{2+}$ solution in one of the cell culture dishes. Place two loops of $4-0$ surgical silk dipped in $70 \%$ ethyl alcohol (Subheading 2.1, item 9) around the cannula.

\subsubsection{Removing the Heart}

1. Administer an intraperitoneal (IP) injection of heparin (1500U/kg; Subheading 2.1, item 6) to an adult rat (200-250 g) (see Note 5). Wait 15 min for adequate heparinization, and then inject 150-200 $\mathrm{mg} / \mathrm{kg}$ Nembutal (Subheading 2.1, item 7). Prepare the digestion solution (Subheading 2.1, items 18-20) during this heparinization period.

2. Sterile gloves should be worn to remove the heart and along with sterile surgical instruments. Sterilize the abdomen with $70 \%$ ethyl alcohol solution (Subheading

\footnotetext{
${ }^{5} \mathrm{~A}$ small volume of Nembutal (Subheading 2.1 item $7 ;<0.1 \mathrm{cc}$ ) can be added to the heparin (Subheading 2.1 item 6 ) syringe. For both injections, bring the volume up to 6-7 cc using 0.9\% saline solution (Subheading 2.1 item 7).
} 
2.1, item 9). Use the Mayo-Stille scissors to cut open the thorax on either side of the sternum and move the sternum with the standard pattern forceps to expose the heart. Holding the heart gently between the thumb and forefinger, excise the heart with a single cut above the aortic arch (see Note 6).

3. Immerse the heart in ice-cold $\mathrm{KHB}+\mathrm{Ca}^{2+}(50 \mathrm{~mL}$ beaker) (Subheading 2.1 , item 17) and rinse away blood by gently massaging the heart.

4. Place the heart in the $\mathrm{KHB}+\mathrm{Ca}^{2+}$-containing cell culture dish (Subheading 2.1, item 17) without the syringe. Gently remove the fascia around the aorta with Dumont \#4 forceps until the majority of the fascia is removed from the aorta. Carefully remove any aortic branches from the top of the aorta with a single cut using fine dissection scissors. Keep the heart immersed in $\mathrm{KHB}+\mathrm{Ca}^{2+}$ during this process. Gently place aorta on the tip of the cannula without introducing bubbles into the aorta or heart. Secure the heart to the cannula with surgical silk (see Note 7). Test the attachment with a gentle flush from the syringe. The heart should enlarge slightly and stay attached to the cannula.

5. Turn the lower stopcock to allow the $\mathrm{KHB}+\mathrm{Ca}^{2+}$ buffer (Subheading 2.1, item 17; syringe \#1) to flow in a rapid, dropwise manner. While transferring the heart to the perfusion apparatus, gently and continuously deliver $\mathrm{KHB}+\mathrm{Ca}^{2+}$ via the syringe. Top off the cannula with $\mathrm{KHB}+\mathrm{Ca}^{2+}$ prior to removing the syringe and attaching the cannula/heart to the lower stopcock on the perfusion apparatus.

\subsubsection{Retrograde Perfusion of the Heart}

1. Perfuse the heart for $5 \mathrm{~min}$ with $\mathrm{KHB}+\mathrm{Ca}^{2+}$ (Subheading 2.1, item 17; syringe \#1). The perfusion rate during this time should be $6-10 \mathrm{~mL} / \mathrm{min}$ (see Note 8).

2. After $3 \mathrm{~min}$, transfer the oxygenator to syringe $\# 2$ containing $\mathrm{KHB}-\mathrm{Ca}^{2+}$ (Subheading 2.1, item 16), then wait an additional $2 \mathrm{~min}$ to turn the changeover stopcock to the open position for syringe \#2 $\left(\mathrm{KHB}_{-} \mathrm{Ca}^{2+}\right)$. Perfuse the heart with $\mathrm{KHB}^{-\mathrm{Ca}^{2+}}$ for $5 \mathrm{~min}$ (see Note 9). After 3 min of perfusion with $\mathrm{KHB}-\mathrm{Ca}^{2+}$, adjust the syringe volume to $35 \mathrm{~mL}$ with $\mathrm{KHB}-\mathrm{Ca}^{2+}$ and add all of the digestion solution (Subheading 2.1, item 20) using the drain tubing (final volume $60 \mathrm{~mL}$ ). Place the heart in a $25 \mathrm{~mL}$ beaker and allow the perfusate to rise to level where the heart is partially or fully submerged in buffer. Then, position the tip of the reperfusion tubing (a small piece of PE-20 tubing) near the top of the perfusate against the glass interface and away from the heart. Perfuse the heart in digestion solution for 15-18 min at a rate of up to $10 \mathrm{~mL} / \mathrm{min}$ (see Note 9).

\footnotetext{
${ }^{6}$ When removing the heart, cut upward to obtain as much of the aorta as possible.

${ }^{7}$ When positioning the heart on the cannula, ensure that the tip of the cannula is visible through the wall of the aorta. The cannula should not extend into the ventricle.

${ }^{8}$ The heart often beats during perfusion with $\mathrm{KHB}+\mathrm{Ca}^{2+}$ (Sub-heading 2.1 item 17) and this is a sign of good perfusion. A flow rate greater than $15 \mathrm{~mL} / \mathrm{min}$ indicates the cannula position and/or aortic vessel are compromised during the heart perfusion.

${ }^{9}$ Hearts should no longer beat during the $\mathrm{Ca}^{2+}$-free KHB (Sub-heading 2.1 item 16) perfusion. As described in note 8, the perfusion rate should not exceed $15 \mathrm{~mL} / \mathrm{min}$. If perfusion exceeds this rate after addition of the digestion solution, the heart should be immediately removed and minced as described in Subheading 3.1.3 \#4.
} 
3. Add $3 \times 150 \mu \mathrm{L}$ aliquots of $100 \mathrm{mM} \mathrm{CaCl}_{2}$ (Subheading 2.1, item 15) to syringe containing the $\mathrm{KHB}^{-\mathrm{Ca}^{2+}}$ (Subheading 2.1, item 16) with digestion solution (syringe \#2) every $30 \mathrm{~s}$ for $1.5 \mathrm{~min}$. Add $50 \mu \mathrm{L}$ of $100 \mathrm{mM} \mathrm{CaCl}_{2}$ directly to the solution surrounding the heart at the end of $1.5 \mathrm{~min}$. Continue perfusion for an additional 15-18 min (see Note 9).

4. At the end of this interval, turn the changeover stopcock to stop perfusion, remove the cannula containing the heart from the apparatus and place the heart in a sterile cell culture dish. Remove the aorta, any remaining fascia, and the atria from the heart. Drain all of the digestion solution (Subheading 2.1, item 20) from syringe \#2 and the associated tubing into a sterile $100 \mathrm{~mL}$ beaker. Then, mince the ventricles into 5-6 pieces with fine dissection scissors, and place into a sterile $50 \mathrm{~mL}$ beaker containing $15-20 \mathrm{~mL}$ of warm digestion solution. Cover the remaining digestion solution with Parafilm and store in a $37{ }^{\circ} \mathrm{C}, 5 \% \mathrm{CO}_{2}$ incubator. Cover the beaker containing the minced heart pieces with Parafilm to minimize contamination.

\subsubsection{Myocyte Isolation}

1. A small piece of PE-20 tubing connected via larger Tygon ${ }^{\circledR}$ tubing is used to oxygenate the minced ventricle with $\mathrm{O}_{2}$ gas $\left(95 \% \mathrm{O}_{2}-5 \% \mathrm{CO}_{2}\right)$. Treat the PE-20 tubing tip with $70 \%$ ethyl alcohol (Subheading 2.1, item 9), allow tip to air-dry, and then place tip just inside the beaker adjacent to the Parafilm. Gently swirl the minced ventricular tissue in a $37^{\circ} \mathrm{C}$ water bath.

2. After $5 \mathrm{~min}$, collect the supernatant into a sterile Blue Max tube $(15 \mathrm{~mL}$; DB Falcon $^{\mathrm{TM}}$ ) using a silanized triturator to transfer the solution. Centrifuge in a tabletop clinical centrifuge for $10 \mathrm{~s}$ at $45 \times g$. This supernatant is generally discarded because there are few rod-shaped cells, but this first digestion is highly variable and should be determined by each lab.

3. Add fresh, warm digestion solution (10-15 mL; Subheading 2.1 item 20) to the remaining ventricular tissue. Repeat the swirling incubation in water bath at $37{ }^{\circ} \mathrm{C}$ for 5-10 min (Subheading 3.1.4 \# 1), then gently repeat the trituration process. During this second digestion, the trituration pipet can be used to gently dissociate tissue (see Note 10). Briefly triturate $(<30 \mathrm{~s})$ if tissue is soft and transfer supernatant to sterile Blue Max tube (15 mL; DB Falcon $\left.{ }^{\mathrm{TM}}\right)$. Add fresh warm digestion solution to remaining ventricular tissue and store in the $37^{\circ} \mathrm{C}$ humidified, $5 \% \mathrm{CO}_{2}$ incubator until the next swirling incubation. Collect the supernatant and centrifuge in a tabletop clinical centrifuge at $45 \times g$ for $10 \mathrm{~s}$ to pellet the myocytes.

4. Gently aspirate off the supernatant from the cell pellet in the blue max tube and gently add $5 \mathrm{~mL}$ of warm cell equilibration media $\left(2 \% \mathrm{BSA}+\mathrm{KHB}+\mathrm{Ca}^{2+}\right.$;

\footnotetext{
${ }^{10}$ When triturating, tissue should not be forced up into the pipet. Tissue should only be dislodged with a gentle and continuous up and down motion. If tissue has not digested enough to be softened, continue to incubate in digestion solution and refrain from forcing tissue through the pipet tip.
} 
Subheading 2.2 item 2) down the side of the tube (see Note 11). Resuspend cells in media by gently inverting the tube and place tube in $37{ }^{\circ} \mathrm{C}$ incubator.

5. Repeat the previous water bath incubation and trituration steps (Subheading 3.1.4 \#3-4). Collect supernatant and centrifuge, remove supernatant from the tube and resuspend the cell pellet in $5 \mathrm{~mL}$ cell equilibration media (Subheading 2.2 item 2; Subheading 3.1.4 \#3-4). This digestion process can be repeated for another 1-2 rounds, until the heart has largely digested and/or all the digestion solution has been used. Triturate the tissue and begin using a smaller bore triturator as the tissue is progressively digested.

6. Place the Cellector in a new cell culture dish and pipette the contents of the beaker through the Cellector. Then, pipette the solution into a sterile $15 \mathrm{~mL}$ Blue Max tube (DB Falcon ${ }^{\mathrm{TM}}$ ) and pellet the myocytes by centrifugation as described (Subheading 3.1.4 \#3).

7. Aspirate supernatant from both tubes. Gently resuspend cell pellets in warm, fresh cell equilibration media ( $2 \% \mathrm{BSA}+\mathrm{KHB}+\mathrm{Ca}^{2+}$; Subheading 2.2 item 2$)$ and pool aliquots into a single tube with a final volume of $10 \mathrm{~mL}$ or less.

8. Over a $15 \mathrm{~min}$ period, add $25 \mu \mathrm{L}$ of $100 \mathrm{mM} \mathrm{CaCl}_{2}$ (Subheading 2.1 item 15) every 5 min. Resuspend cells with a gentle rocking motion after each addition of $\mathrm{Ca}^{2+}$ to bring the final $\mathrm{Ca}^{2+}$ concentration to $1.8 \mathrm{mM}$. Store the tube in the $37{ }^{\circ} \mathrm{C}$ incubator between $\mathrm{Ca}^{2+}$ additions. After the final $\mathrm{Ca}^{2+}$ addition, incubate the myocytes at 37 ${ }^{\circ} \mathrm{C}$ for $5 \mathrm{~min}$. Then, pellet the cells by centrifugation (Subheading 3.1.4 \#3), and resuspend the pellet in $3 \mathrm{~mL}$ of a 1:1 ratio of DMEM + P/S (Subheading 2.2 item 3) and DMEM + $10 \% \mathrm{FBS}+\mathrm{P} / \mathrm{S}$ (Subheading 2.2 item 4).

9. During the cell incubation in equilibration buffer, prepare laminin-coated coverslips. A $22 \mathrm{~mm}^{2}$ glass coverslip is placed in each well of a sterile flat-bottom, 6-well tissue culture plate, and UV treated for $10 \mathrm{~min}$ in a biosafety cabinet. Add $100 \mu \mathrm{L}$ laminin ( $40 \mathrm{mg} / \mathrm{mL}$; Subheading 2.2 item 1) to the center of each coverslip. A small drop of laminin is initially added under the coverslip to affix it to the 6well plate and the remainder is pipetted in the middle of each coverslip. Treat laminin coated coverslips with UV light for an additional $10 \mathrm{~min}$, and cover until cells are ready to plate.

10. Transfer an aliquot of resuspended myocytes to a cleaned hemocytometer then count the number of rod-shaped myocytes and total number of myocytes in all nine fields. Calculate the percentage of live cells:

$$
\text { Rods } / \text { Total Cells } \times 100 \%=\% \text { Viability }
$$

Calculate the total amount of rod-shaped myocytes in the preparation:

Total rod-shaped cells $/ 9 \times$ total resuspension volume $=$ number of cells $\times 10^{4}$

\footnotetext{
${ }^{11}$ Preheat the cell equilibration media (2\% BSA $+\mathrm{KHB}+\mathrm{Ca}^{2+}$; Subheading 2.2 item 2), DMEM + P/S (Subheading 2.2 item 3) and $\mathrm{DMEM}+10 \% \mathrm{FBS}+\mathrm{P} / \mathrm{S}$ (Subheading 2.2 item 4) prior to use with the myocytes.
} 
Adjust the volume so the myocyte concentration is $1 \times 10^{5}$ rod shaped cells $/ \mathrm{mL}$ using media containing $5 \%$ FBS (i.e., maintain the 1:1 ratio of DMEM + P/S and $\mathrm{DMEM}+10 \% \mathrm{FBS}+\mathrm{P} / \mathrm{S}$ when adjusting the total volume) (see Note 12). Store the myocytes in the incubator until ready for plating.

\subsection{Gene Transfer into Rat Cardiac Myocytes}

Work with recombinant adenovirus requires prior BL2 approval. Viral vectors should be handled in a biosafety cabinet and the surface should be treated with $60 \%$ Lysol followed by $70 \%$ ethyl alcohol with each entry and exit from the cabinet. Personnel handling vectors should wear safety glasses, gloves, and a lab coat. The biosafety cabinet should be equipped with a vacuum system containing tandem Erlenmeyer flasks attached to a $0.1 \mu \mathrm{m}$ approved vacuum filter. The Erlenmeyer used for direct collection of media and a $2 \mathrm{~L}$ beaker should have adequate amounts of $10 \%$ bleach to treat all virus for at least 20 min prior to discarding excess media. All plasticware and glassware should be treated with $10 \%$ bleach for $20 \mathrm{~min}$ and then disposed of in a biocontainment bag.

1. Aspirate excess laminin from each coverslip (Subheading 3.1.4 \#9) and pipette 200 $\mu \mathrm{L}$ of resuspended cells onto the laminin-coated surface $\left(2 \times 10^{4}\right.$ cells/ coverslip $)$ (see Note 13).

2. Carefully place the plates into the incubator $\left(37^{\circ} \mathrm{C} ; 5 \% \mathrm{CO}_{2}\right)$ and incubate the cells for $2 \mathrm{~h}$.

3. During the incubation period, dilute the adenoviral stocks in sterile microfuge tubes to the desired multiplicity of infection (MOI) with DMEM + P/S (Subheading 2.2 item 3) (see Notes $\mathbf{1 4}$ and $\mathbf{1 5}^{\mathbf{1 5}}$ ). Store diluted viruses in the $37^{\circ} \mathrm{C}$ incubator until needed.

4. At the end of the $2 \mathrm{~h}$ incubation, aspirate the excess media from each coverslip. Pipette $200 \mu \mathrm{L}$ of the diluted adenovirus onto the cells (see Note 14). Return the plates to the incubator for an additional $1 \mathrm{~h}$.

\subsection{Culturing Rat Cardiac Myocytes}

1. One hour after the addition of virus, add $2 \mathrm{~mL}$ M199 + P/S (Subheading 2.2 item 5) to each well and return the plates to the incubator (see Note 16).

\footnotetext{
12 Adjust the volume of media used to resuspend the myocytes according to the size of the pellet. If the pellet is small, use $1.5 \mathrm{~mL}$ $\mathrm{DMEM}+\mathrm{P} / \mathrm{S}$ (Subheading 2.2 item 3) and $1.5 \mathrm{~mL}$ DMEM + $10 \% \mathrm{FBS}+\mathrm{P} / \mathrm{S}$ (Subheading 2.2 item 4) (total volume $=3 \mathrm{~mL}$ ). If a large pellet forms, increase the total volume as necessary. This will aid in myocyte counting.

13 Resuspend the cells by gentle inversion prior to each plate. This prevents the myocytes from pelleting, allowing for even myocyte application to each coverslip.

${ }^{14}$ The gene transfer protocol described is optimized for high-titer recombinant adenovirus. High titer preparations contain $\sim 10^{12}$ viral particles $/ \mathrm{mL}$ and $10^{10}$ plaque forming units $(\mathrm{pfu}) / \mathrm{mL}$ of virus. Prior to gene transfer, the virus is diluted to a specific multiplicity of infection (MOI), the number of plaque forming units (pfu)/myocyte. For sarcomeric proteins, $200 \mathrm{MOI}$ is sufficient for adenoviralmediated gene transfer with a viral vector driven by a mouse cytomegalovirus immediately early promoter (CMV) [2, 9, 42]. For recombinant adenoviral-mediated gene transfer of non-sarcomeric proteins, $10 \mathrm{MOI}$ achieves $80 \%$ myocyte transduction [41]. Control cells are incubated with the same volume of DMEM + P/S (Subheading 2.2 item 3) without virus during the gene transfer

${ }^{15}$ Viral aliquots are stored at $-80{ }^{\circ} \mathrm{C}$ and thawed on ice prior to dilution. Multiple freeze-thaw cycles should be avoided by making single-use aliquots of the virus.

${ }^{16}$ Isolated myocytes are not cultured in serum-containing media for contractile function studies, as serum promotes myocyte dedifferentiation of the sarcomere $[2,9]$.
} 
2. Replace the media in each well with $2 \mathrm{~mL}$ pre-warmed M199 + P/S (Subheading 2.2 item 5) $24 \mathrm{~h}$ after gene transfer.

3. Change the media every other day after this initial media change.

\section{Acknowledgements}

Funding from the National Institutes of Health HL067254 (MVW) supported this work, NIH T-32GM007315 (SEL), and an American Heart Association Predoctoral Award AHA12PRE8830022 (SEL).

\section{References}

1. Davis J, et al. Designing heart performance by gene transfer. Physiol Rev. 2008; 88(4):1567-1651. [PubMed: 18923190]

2. Westfall MV, et al. Adenovirus-mediated myofilament gene transfer into adult cardiac myocytes. Methods Cell Biol. 1997; 52:307-322. [PubMed: 9379958]

3. Panchal RG, et al. Gene transfer: manipulating and monitoring function in cells and tissues. Clin Exp Pharmacol Physiol. 2001; 28(8):687-691. [PubMed: 11473537]

4. McWhinney CD, Hansen C, Robishaw JD. Alpha-1 adrenergic signaling in a cardiac murine atrial myocyte (HL-1) cell line. Mol Cell Biochem. 2000; 214(1-2):111-119. [PubMed: 11195782]

5. Beaumont J, et al. Overexpression of human truncated peroxisome proliferator-activated receptor alpha induces apoptosis in HL-1 cardiomyocytes. Cardiovasc Res. 2008; 79(3):458-463. [PubMed: 18440986]

6. Ting YK, et al. Transcriptional activation of the anchoring protein SAP97 by heat shock factor (HSF)-1 stabilizes K(v) 1.5 channels in HL-1 cells. Br J Pharmacol. 2011; 162(8):1832-1842. [PubMed: 21232033]

7. Louch WE, Sheehan KA, Wolska BM. Methods in cardiomyocyte isolation, culture, and gene transfer. J Mol Cell Cardiol. 2011; 51(3):288-298. [PubMed: 21723873]

8. Monge $\mathrm{C}$, et al. Comparative analysis of the bioenergetics of adult cardiomyocytes and nonbeating HL-1 cells: respiratory chain activities, glycolytic enzyme profiles, and metabolic fluxes. Can J Physiol Pharmacol. 2009; 87(4):318-326. [PubMed: 19370085]

9. Rust EM, Westfall MV, Metzger JM. Stability of the contractile assembly and Ca2 + -activated tension in adenovirus infected adult cardiac myocytes. Mol Cell Biochem. 1998; 181(1-2):143-155. [PubMed: 9562251]

10. Kirshenbaum LA, et al. Highly efficient gene transfer into adult ventricular myocytes by recombinant adenovirus. J Clin Invest. 1993; 92(1):381-387. [PubMed: 8326005]

11. Kampert, SE.; Devaney, E.; Westfall, MV. Gene transfer and expression in animal cells.. In: Cseke, AKLJ.; Kaufman, PB.; Westfall, MV., editors. Handbook of Molecular and Cellular Methods in Biology and Medicine. CRC Press; Boca Raton, Florida: 2011. p. 557-578.

12. Jaenisch R. Germ line integration and Mendelian transmission of the exogenous Moloney leukemia virus. Proc Natl Acad Sci U S A. 1976; 73(4):1260-1264. [PubMed: 1063407]

13. Pfeifer A. Lentiviral transgenesis. Transgenic Res. 2004; 13(6):513-522. [PubMed: 15672832]

14. Fassler R. Lentiviral transgene vectors. EMBO Rep. 2004; 5(1):28-29. [PubMed: 14710182]

15. Wells K, Moore K, Wall R. Transgene vectors go retro. Nat Biotechnol. 1999; 17(1):25-26. [PubMed: 9920263]

16. Kass-Eisler A, et al. Quantitative determination of adenovirus-mediated gene delivery to rat cardiac myocytes in vitro and in vivo. Proc Natl Acad Sci U S A. 1993; 90(24):11498-11502. [PubMed: 8265580]

17. Hofmann A, et al. Efficient transgenesis in farm animals by lentiviral vectors. EMBO Rep. 2003; 4(11):1054-1060. [PubMed: 14566324]

18. Izsvak Z, et al. Efficient stable gene transfer into human cells by the Sleeping Beauty transposon vectors. Methods. 2009; 49(3):287-297. [PubMed: 19615447] 
19. Merkulov $\mathrm{S}$, et al. In vivo cardiac myosin binding protein $\mathrm{C}$ gene transfer rescues myofilament contractile dysfunction in cardiac myosin binding protein $\mathrm{C}$ null mice. Circ Heart Fail. 2012; 5(5): 635-644. [PubMed: 22855556]

20. Lee CJ, et al. Promoter-specific lentivectors for long-term, cardiac-directed therapy of Fabry disease. J Cardiol. 2011; 57(1):115-122. [PubMed: 20846825]

21. Fassler M, et al. Preferential lentiviral targeting of astrocytes in the central nervous system. PLoS One. 2013; 8(10):e76092. [PubMed: 24098426]

22. Wang L, et al. Long-term effect of neuronal nitric oxide synthase over-expression on cardiac neurotransmission mediated by a lentiviral vector. J Physiol. 2009; 587(Pt 14):3629-3637. [PubMed: 19491240]

23. Pacak CA, Byrne BJ. AAV vectors for cardiac gene transfer: experimental tools and clinical opportunities. Mol Ther. 2011; 19(9):1582-1590. [PubMed: 21792180]

24. Deyle DR, Russell DW. Adeno-associated virus vector integration. Curr Opin Mol Ther. 2009; 11(4):442-447. [PubMed: 19649989]

25. Huang S, et al. Adeno-associated virus Rep-mediated targeting of integrase-defective retroviral vector DNA circles into human chromosome 19. Biochem Biophys Res Commun. 2012; 417(1): 78-83. [PubMed: 22138242]

26. Park F. Lentiviral vectors: are they the future of animal transgenesis? Physiol Genomics. 2007; 31(2):159-173. [PubMed: 17684037]

27. Coyne CB, Bergelson JM. CAR: a virus receptor within the tight junction. Adv Drug Deliv Rev. 2005; 57(6):869-882. [PubMed: 15820557]

28. Bergelson JM, et al. Isolation of a common receptor for Coxsackie B viruses andadenoviruses 2 and 5. Science. 1997; 275(5304):1320-1323. [PubMed: 9036860]

29. Fechner H, et al. Induction of coxsackievirus-adenovirus-receptor expression during myocardial tissue formation and remodeling: identification of a cell-to-cell contact-dependent regulatory mechanism. Circulation. 2003; 107(6):876-882. [PubMed: 12591759]

30. Westfall MV, Lee AM, Robinson DA. Differential contribution of troponin I phosphorylation sites to the endothelin-modulated contractile response. J Biol Chem. 2005; 280(50):41324-41331. [PubMed: 16236710]

31. Westfall MV, Rust EM, Metzger JM. Slow skeletal troponin I gene transfer, expression, and myofilament incorporation enhances adult cardiac myocyte contractile function. Proc Natl Acad Sci U S A. 1997; 94(10):5444-5449. [PubMed: 9144257]

32. Rust EM, Albayya FP, Metzger JM. Identification of a contractile deficit in adult cardiac myocytes expressing hypertrophic cardiomyopathy-associated mutant troponin T proteins. J Clin Invest. 1999; 103(10):1459-1467. [PubMed: 10330428]

33. Michele DE, Albayya FP, Metzger JM. Direct, convergent hypersensitivity of calcium-activated force generation produced by hypertrophic cardiomyopathy mutant alpha-tropomyosins in adult cardiac myocytes. Nat Med. 1999; 5(12):1413-1417. [PubMed: 10581085]

34. Herron TJ, et al. Ca2 + -independent positive molecular inotropy for failing rabbit and human cardiac muscle by alpha-myosin motor gene transfer. FASEB J. 2010; 24(2):415-424. [PubMed: 19801488]

35. Day SM, Westfall MV, Metzger JM. Tuning cardiac performance in ischemic heart disease and failure by modulating myofilament function. J Mol Med (Berl). 2007; 85(9):911-921. [PubMed: 17396243]

36. del Monte F, et al. Targeting phospholamban by gene transfer in human heart failure. Circulation. 2002; 105(8):904-907. [PubMed: 11864915]

37. Amalfitano A, Parks RJ. Separating fact from fiction: assessing the potential of modified adenovirus vectors for use in human gene therapy. Curr Gene Ther. 2002; 2(2):111-133. [PubMed: 12109210]

38. $\mathrm{Ng} \mathrm{P}$, et al. A high-efficiency Cre/loxP-based system for construction of adenoviral vectors. Hum Gene Ther. 1999; 10(16):2667-2672. [PubMed: 10566894]

39. $\mathrm{Ng} \mathrm{P}$, et al. An enhanced system for construction of adenoviral vectors by the twoplasmid rescue method. Hum Gene Ther. 2000; 11(5):693-699. [PubMed: 10757349] 
40. Haworth RA, Hunter DR, Berkoff HA. The isolation of Ca2 + -resistant myocytes from the adult rat. J Mol Cell Cardiol. 1980; 12(7):715-723. [PubMed: 7411647]

41. Hwang H, et al. PKCbetaII modulation of myocyte contractile performance. J Mol Cell Cardiol. 2012; 53(2):176-186. [PubMed: 22587992]

42. Lang SE, et al. Myofilament incorporation and contractile function after gene transfer of cardiac troponin I Ser43/45Ala. Arch Biochem Biophys. 2013; 535(1):49-55. [PubMed: 23318976] 